\title{
Conspecific Brood Parasitism in Common Eiders (Somateria mollissima): Do Brood Parasites Target Safe Nest Sites?
}

Author(s): Alain P. Lusignan, Katherine R. Mehl, Ian L. Jones, and Mark L. Gloutney

Source: The Auk, 127(4):765-772. 2010.

Published By: The American Ornithologists' Union

URL: http://www.bioone.org/doi/full/10.1525/auk.2010.09207

BioOne (www.bioone.org) is a nonprofit, online aggregation of core research in the biological, ecological, and environmental sciences. BioOne provides a sustainable online platform for over 170 journals and books published by nonprofit societies, associations, museums, institutions, and presses.

Your use of this PDF, the BioOne Web site, and all posted and associated content indicates your acceptance of BioOne's Terms of Use, available at www.bioone.org/page/terms of use.

Usage of BioOne content is strictly limited to personal, educational, and non-commercial use. Commercial inquiries or rights and permissions requests should be directed to the individual publisher as copyright holder. 


\title{
CONSPECIFIC BROOD PARASITISM IN COMMON EIDERS (SOMATERIA MOLLISSIMA): DO BROOD PARASITES TARGET SAFE NEST SITES?
}

\author{
Alain P. Lusignan, ${ }^{1,4}$ Katherine R. Mehl, ${ }^{2,5}$ Ian L. Jones, ${ }^{1}$ and Mark L. Gloutney ${ }^{3}$ \\ ${ }^{1}$ Department of Biology, Memorial University, St. John's, Newfoundland A1B 3X9, Canada; \\ ${ }^{2}$ Ducks Unlimited Canada, 6 Bruce Street, Mount Pearl, Newfoundland A1N 4T3, Canada; and \\ ${ }^{3}$ Ducks Unlimited Canada, P.O. Box 430, Amherst, Nova Scotia B4H 3Z5, Canada
}

\begin{abstract}
Several hypotheses have been proposed to explain the evolution of conspecific brood parasitism (CBP), and recent studies suggest that nest predation may be an important factor in shaping this behavior. We assessed whether individuals that engage in parasitic laying preferentially deposit their eggs in safe nest sites (i.e., risk assessment hypothesis). We tested the predictions of this hypothesis using a population of Common Eiders (Somateria mollissima dresseri) nesting at Table Bay, Labrador, Canada, in 2007. Common Eiders at this location nest in three habitats (dense woody vegetation, open grassy vegetation, and nest shelters) that vary in their exposure to avian predators. We used isoelectric focusing electrophoresis of egg albumen to quantify the frequency and distribution of CBP among habitats. Nest-site safety did not explain patterns of CBP among habitats, given that nests in dense woody vegetation had the highest probability of survival $(0.70 ; 95 \%$ confidence interval $[\mathrm{CI}]: 0.50-0.89)$ yet had the lowest frequency of CBP (33\%). There was also no indication that parasitized and nonparasitized nests differed in their probability of nest survival $(0.65$ [95\% CI: $0.41-0.83$ ] vs. 0.58 [95\% CI: 0.33-0.80]). We propose explanations for why our data did not support the risk assessment hypothesis. Received 20 October 2009, accepted 8 April 2010.
\end{abstract}

Key words: Common Eider, conspecific brood parasitism, habitat selection, nest predation, nest survival, protein fingerprinting, Somateria mollissima.

\section{Le parasitisme conspécifique de nid chez Somateria mollissima: les parasites de nid ciblent-ils les sites de nidification sûrs?}

RÉSUMÉ.-Plusieurs hypothèses ont été proposées afin d'expliquer l'évolution du parasitisme conspécifique de nid (PCN). Des études récentes suggèrent que la prédation des nids puisse être un facteur important dans l'élaboration de ce comportement. Nous avons évalué si les individus qui se livrent à la ponte parasitaire déposaient préférentiellement leurs œufs dans des nids sûrs (hypothèse d'évaluation des risques). Nous avons testé les prédictions de cette hypothèse sur une population de Somateria mollissima dresseri nichant à Table Bay, au Labrador, Canada, en 2007. À cet endroit, S. mollissima niche dans trois habitats (végétation arborescente dense, végétation herbacée ouverte et abris pour les nids) qui diffèrent en termes d'exposition aux prédateurs aviens. Nous avons utilisé l'électrophorèse isoélectrique de l'albumen des œufs afin de quantifier la fréquence et la répartition du PCN entre les habitats. La sécurité des sites de nidification n'a pas expliqué les patrons de PCN entre les habitats, car les nids situés dans la végétation arborescente dense avaient la probabilité de survie la plus élevée (0,70; intervalle de confiance [IC] à 95\%: 0,50-0,89) et la plus faible fréquence de PCN (33\%). De plus, il n'y avait aucune indication que les nids parasités et non-parasités différaient dans leur probabilité de survie (0,65 [IC 95\%: 0,41-0,83] vs 0,58 [95\% IC: $0,33-0,80]$ ). Nous proposons des explications sur le pourquoi nos données ne supportaient pas l'hypothèse d'évaluation des risques.

Parental investment is energetically costly (King 1974, Andersson 1984) and can expose adults to additional mortality risks during nest attendance (Sargeant and Raveling 1992). Broodparasitic individuals avoid these costs. Female birds that lay their eggs in the nests of other females, such that the care of the eggs and offspring is provided by others, may live longer and produce more offspring over a lifetime (Andersson 1984, Åhlund and Andersson 2001). However, because brood parasites abandon the care of their offspring to others, the selection of suitable hosts to raise their young has direct fitness consequences. Determination of where females choose to lay their eggs and how their decisions are made is important in our understanding of brood-parasite behavior.

If brood parasitism is to be evolutionarily advantageous, the parasites should select host species and nest sites that maximize the probability of their offspring's survival (Hauber 2000). Some parasitic species are generalists that employ a "shotgun" strategy

${ }^{4}$ Present address: 907 La Baie, Rigaud, Quebec J0P 1P0, Canada. E-mail: aplusignan@gmail.com

${ }^{5}$ Present address: Department of Biology, University of North Dakota, 10 Cornell Street, Grand Forks, North Dakota 58202, USA.

The Auk, Vol. 127, Number 4, pages 765-772. ISSN 0004-8038, electronic ISSN 1938-4254. @ 2010 by The American Ornithologists' Union. All rights reserved. Please direct all requests for permission to photocopy or reproduce article content through the University of California Press's Rights and Permissions website, http://www.ucpressjournals. com/reprintInfo.asp. DOI: 10.1525/auk.2010.09207 
to randomly distribute their eggs among host nests (e.g., Molothrus spp.; Rothstein 1976, Kattan 1997). However, this approach may be favored only when host defenses in the avian community are not highly developed and when brood parasites have especially high fecundity. When host defenses are present or when brood parasites have low fecundity, specialized strategies and nonrandom host selectivity should evolve over time (Rothstein 1990, Davies 2000, Krüger 2007).

Brood parasites must overcome several challenges to be successful. They should select host species that have an appropriate diet to feed their offspring and that have an incubation length greater than or equal to their own. Suitable hosts must be in sufficient abundance and density to make parasitic laying possible, and the breeding cycle of the brood parasite must be in synchrony with that of the host. Brood parasites must also avoid or overcome host defenses such as aggressive nest defense and egg rejection (Rothstein 1990, Sealy and Bazin 1995, Sorenson 1997). Brood parasites may increase their fitness further if they are able to make finer-scale laying decisions such that they parasitize higherquality parents (Soler et al. 1995, Avilés 2008, Polačiková et al. 2009) or preferentially lay in safer nest sites (Hauber 2001, 2009; Pöysä 2006).

Many of the challenges of selecting suitable hosts are resolved when brood parasites lay their eggs in the nests of conspecifics. Conspecific brood parasitism (CBP) accounts for $70 \%$ of all known taxonomic diversity of brood parasitism (234 species CBP vs. 100 obligate interspecific brood parasites; Yom-Tov and Geffen 2006) because fewer adaptations are required to parasitize individuals of the same species. However, CBP still requires sufficient availability of host nests (Lyon 2003) and that hosts are capable of incubating and caring for additional young. This may explain why CBP is biased toward colonial species with precocial young (Rohwer and Freeman 1989, Yom-Tov 2001). However, even in CBP it may be evolutionarily advantageous for parasites to discriminate among potential hosts to find the optimal location to deposit their eggs.

Nest predation is a primary selective force in shaping avian nesting behavior (Ricklefs 1969; Martin 1988, 1993), and recent studies have examined how nest predation influences the frequency and distribution of parasitic eggs among nest sites (Pöysä 2003, 2006; Roy Nielsen et al. 2008). The "risk assessment hypothesis" posits that when nest predation differs among nest sites, individuals may be able to increase an egg's probability of survival by preferentially laying in safe nest sites (Pöysä 1999, Pöysä and Pesonen 2007). To date, empirical support for this hypothesis has been restricted to cavity-nesting birds, and it is unknown whether this concept can be generalized to other groups, such as ground-nesting species.

We attempted to assess whether or not Common Eiders (Somateria mollissima dresseri) that engage in parasitic laying preferentially deposited their eggs in safe nest sites (i.e., sites with low predation risk). Conspecific brood parasitism is frequent in Common Eiders (Robertson et al. 1992, Bjorn and Erikstad 1994, Waldeck et al. 2004), and birds at our study area nest in habitats that vary in their vulnerability to nest predation. Our objectives were to (1) compare rates of CBP among nesting habitats, (2) determine whether levels of CBP were correlated with differences in reproductive success among those habitats, and (3) determine whether parasitized and nonparasitized nests differed in their probability of nest survival. Assuming that nest parasites preferentially lay eggs in safe nest sites, we predicted higher rates of CBP at nest sites that offered the most protection from predators.

\section{Methods}

Study site.-Our study was conducted in Table Bay $\left(53^{\circ} 40^{\prime} \mathrm{N}\right.$, $56^{\circ} 26^{\prime} \mathrm{W}$; Fig. 1), Labrador, Canada, in 2007. This area supports the largest number of nesting Common Eiders of the dresseri subspecies on the Labrador coast (Lock 1986). Common Eiders nest on small ( $<12 \mathrm{ha})$ coastal islands in three main habitat types: (1) dense woody vegetation of dwarf spruce (Picea spp.) and Balsam Fir (Abies balsamea) that ranges from 1 to $3 \mathrm{~m}$ in height; (2) open habitats characterized by a mix of grassy, herbaceous, and heath vegetation (e.g., Common Cowparsnip [Heracleum maximum], Scottish Licorice-root [Ligusticum scoticum], and Black Crowberry [Empetrum nigrum]) that rarely exceeds $40 \mathrm{~cm}$ in height; and (3) artificial wooden nest shelters $(1.2 \times 0.9 \times 0.25 \mathrm{~m})$. Approximately 700 artificial nest shelters were located on study islands in the Table Bay area at the time of our study. Although the number and placement of shelters varied, our sampling regime (see below) enabled us to obtain a representative sample of nests across our study islands.

Nest searches.-Islands were searched systematically for nests during the early laying period. We limited the total number of marked nests to every other nest during each island visit in order to minimize disturbance of the population. For each marked nest, we recorded the number of eggs present and numbered the eggs with indelible ink according to the degree of egg staining (Cooper 1978). The darkest or dirtiest egg was assumed to have been laid first. Nest age was determined by candling eggs (Weller 1956). We marked nest bowls using a small wooden stake pushed

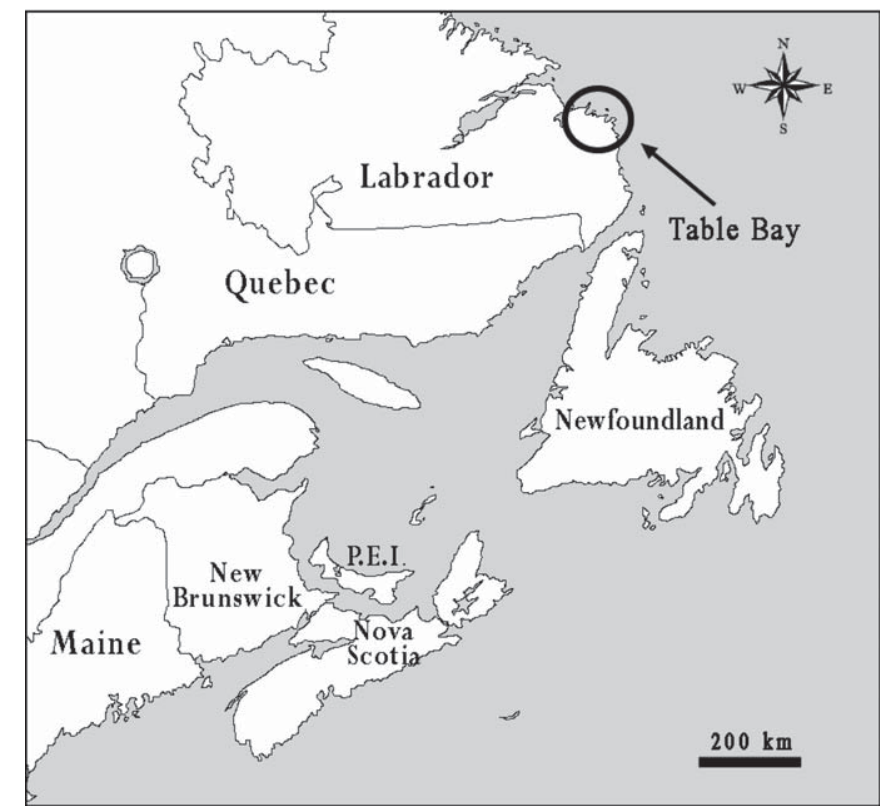

Fig. 1. Map showing the Table Bay study area (circled) in Labrador, Canada, where our study of Common Eider nest survival and conspecific nest parasitism was conducted in 2007. 
into the ground under the nest bowl and recorded nest locations using a global positioning system to facilitate revisits. Nest initiation dates (NID) and predicted hatch dates were calculated by assuming an incubation length of 26 days (Guignion 1968) and a laying interval of one egg per day (Cooch 1965, Swennen et al. 1993). Before leaving the nest site, we covered the eggs with down and nest materials to insulate them and reduce their visibility to avian predators. We revisited nests periodically (every 3 or 4 days) during laying to determine nest status and to check for additional eggs. The revisitation rate was selected to limit observer effect on nest survival and CBP. Final clutch size (CS) was the number of eggs present when incubation began.

Nests were revisited after hatch to determine nest fates. Nests were considered successful if they contained eggshell fragments and egg membranes that separated easily from the shell (Klett et al. 1986, Mabee 1997). We assumed that nests had failed if they lacked signs of successful hatching or contained depredated eggs (broken eggshells with yolk or blood on them) or abandoned eggs. We excluded nests that could not be relocated $(n=3)$ and nests that we suspected were abandoned as a result of our research activities (specifically, when the female was flushed from the nest during egg laying and the nest was found abandoned on the subsequent visit; $n=3$ ).

Albumen sampling and electrophoresis.-We used isoelectric focusing (IEF) electrophoresis of egg albumen to identify clutches that contained parasitic eggs. We obtained egg albumen samples from every nest we encountered that was $<5$ days into incubation, until we reached target sample sizes in each of the three main nesting habitats $\left(\sim 15\right.$ nests habitat $\left.^{-1}\right)$. Albumen samples were collected over 8 days (8-16 June). Previous work had shown that albumen sampling does not affect egg hatchability if it is done early in incubation (Andersson and Åhlund 2001, Waldeck et al. 2004), and therefore we limited sampling to nests that were $<5$ days into incubation. A small hole was made in the blunt end of the egg using a sterile pushpin, and $\sim 0.3 \mathrm{~mL}$ of albumen was extracted using a syringe. The hole was sealed with cyanoacrylate glue (super glue) and was left to dry before the eggs were returned to the nest. We obtained albumen from all eggs within a clutch beginning at the date of nest discovery. We revisited nests 3 or 4 days after the initial visit to obtain albumen samples from any new eggs, and we continued nest visits until albumen had been obtained from the entire clutch. Albumen samples were stored frozen until electrophoresis. We did not analyze albumen from nests that failed before incubation had begun, because final CS could not be determined. However, these nests were included in the analysis of nest survival (see below).

Albumen samples were run on gels with a broad-range $\mathrm{pH}$ gradient (Ready-Gel pH 3-10; Bio-Rad, Hercules, California). The IEF methods were optimized for protein load and stainingdestaining methods. Five microliters of each albumen sample was buffered with $10 \mu \mathrm{L}$ of $50 \% \mathrm{v} / \mathrm{v}$ glycerol. Two Ready-Gels were loaded into a Bio-Rad Miniprotean apparatus. Cathode buffer (20 mM lysine [free acid, Sigma L5501] and $20 \mathrm{mM}$ arginine [free acid, Fluka 11009]) was added to the upper chamber, and anode buffer ( $7 \mathrm{mM}$ phosphoric acid) was added to the lower chamber. The wells of the precast gel were rinsed with buffer prior to loading the samples. All eggs from the same clutch were run side by side on the same gel. One well per gel was loaded with $5 \mu \mathrm{L}$ of IEF standard (BroadRange pI 4.45-9.96; Bio-Rad). Gels were run in a stepwise manner with voltages of $100 \mathrm{~V}$ for $60 \mathrm{~min}, 250 \mathrm{~V}$ for 60 $\mathrm{min}$, and $500 \mathrm{~V}$ for $30 \mathrm{~min}$, at a current of 5-25 mA. After electrophoresis, each gel was placed in $50 \mathrm{~mL}$ of IEF staining solution (Bio-Rad) and incubated for $45 \mathrm{~min}$ on a shaking platform. The stain was then removed and $50 \mathrm{~mL}$ of destaining solution $(40 \%$ methanol, $10 \%$ acetic acid) was added to each gel. Gels continued to be incubated on the shaking platform and the destaining solution was changed every 2 to 3 hours until all background stain had been removed from the gel. Gels were placed in distilled water overnight before banding patterns were analyzed. The IEF trials were repeated twice to determine that the numbers of visible bands were consistent among gel runs.

Albumen proteins are exclusively of maternal origin (White 1991). All eggs from a single female have identical protein band patterns, and differences in albumen protein band patterns can be used to identify eggs laid by different females (Andersson and Åhlund 2001, Pilz et al. 2005, Waldeck and Andersson 2006). We scored a nest as being parasitized if it contained at least one egg of different maternal origin. The most common albumen banding pattern in a clutch was considered to have originated from the host (Andersson and Åhlund 2001, Waldeck et al. 2008). We did not explore relatedness between hosts and parasites.

Statistical analyses.-We tested for normality of CS and NID data using the Shapiro-Wilks statistic (PROC UNIVARIATE; SAS Institute 2001). The CS and NID data were not normally distributed, and transformations did not improve normality. Therefore, we used Kruskal-Wallis tests to check for differences in CS and NID among habitats (PROC NPAR1WAY; SAS Institute 2001) and used Bonferroni-adjusted Wilcoxon two-sample tests for post hoc comparisons.

We conducted two separate nest-survival analyses to estimate daily survival rates (DSR) for (1) all nests encountered and (2) the subsample of nests in which we determined egg maternity using IEF. We used the Nest Survival option in program MARK (White and Burnham 1999) to estimate DSR and used the logitlink function for all models. Model selection was based on quasilikelihood Akaike's information criterion (AIC) adjusted for sample size and overdispersion (QAIC; Akaike 1973, Burnham and Anderson 2002). Models were adjusted for overdispersion using the variance inflation factor $(\hat{c})$ from our most parameterized model (Anderson et al. 1994, Burnham and Anderson 2002). There is currently no consensus on how to estimate extrabinomial variation in nest survival data (Dinsmore et al. 2002), but $\hat{c}$ can be used as a conservative method of estimating overdispersion (Schmidt et al. 2006) to avoid selecting a more parameterized model than is supported by the data (Anderson et al. 1994).

In the analysis of all nests encountered, we constructed a set of 18 candidate models in a three-step procedure. First, we examined the effects of nest habitat, island, and albumen sampling on nest survival. We compared the fit of models in which DSR was constant across all nests $\{S\}$ or varied according to nest habitat $\left\{\mathrm{S}_{\mathrm{Hab}}\right\}$ or island $\left\{\mathrm{S}_{\text {Island }}\right\}$. We also examined models in which DSR varied according to whether the nests had been sampled for egg albumen $\left\{\mathrm{S}_{\mathrm{Alb}}\right\}$. We included additive and interactive models between both nest habitat and island with albumen sampling.

Second, for the most parsimonious model $\left\{\mathrm{S}_{\mathrm{Hab}}\right\}$, we tested for variation in DSR in relation to nest age. Because nesting was highly 
synchronous (see below), the effects of nest age and calendar date on DSR could not be differentiated. We assumed that temporal trends reflected the effect of nest age on DSR. We used the following three forms of models to constrain DSR as a function of nest age: (1) linear, where nest survival changed in relation to nest age at a constant rate; (2) quadratic, where nest survival was highest during mid-incubation and lower toward the beginning and end of incubation; and (3) pseudothreshold, where nest survival increased at a constant rate to a point at which the effects of nest age neared, but did not reach, an asymptote. The pseudothreshold model allowed us to account for changes in DSR that were due to differences in female behavior between the laying and incubation periods.

Finally, we added CS and NID as covariates to the most parsimonious model $\left\{\mathrm{S}_{\mathrm{Hab}+\mathrm{LnAge}}\right\}$. All covariates were standardized in MARK. We considered CS as both a linear and a quadratic covariate and assessed the interaction between linear and quadratic CS covariates and nest habitat. Quadratic covariates allowed us to test for the presence of an optimal CS (see Franklin et al. 2000). Because of nest failure during the initiation period, we were unable to obtain final CS values for some nests ( $n=17$; open habitats $=7$, woody vegetation $=6$, nest shelters $=4$ ). For these nests, we replaced the missing CS values with the mean CS for the nests' habitat category. Doing so reduces the variance slightly but does not change the mean of the observed values (Little and Rubin 2003). We used model averaging to obtain estimates of DSR for nests (Burnham and Anderson 2002). We obtained overall nest survival probabilities for habitats and CS values using the product of model-averaged DSRs and derived confidence limits using the delta method (Seber 1982).

We used the chi-square test for goodness-of-fit to test whether nest parasitism was randomly distributed among habitats, and MARK to calculate overall nest survival probabilities for parasitized and nonparasitized clutches using the subsample of nests used in the IEF analysis $(n=40)$. Sample size limited the complexity of candidate models; therefore, we pooled nests from all habitats and estimated nest survival and compared $95 \%$ confidence intervals (CI) using a model with a single fitted parameter for parasitism.

\section{Results}

We monitored 239 Common Eider nests during the study (Table 1). Clutch size differed among habitats $\left(\chi^{2}=17.37, \mathrm{df}=2, P<0.01\right)$, with nests in shelters having larger clutches than nests in open habitats or woody vegetation (Table 1 ; nest shelters vs. open habitats: $Z=$ 3.92, $P<0.01$; nest shelters vs. woody vegetation: $Z=2.70, P=0.07$; open habitats vs. woody vegetation: $Z=-1.89, P=0.06$ ). Nest initiation dates ranged from 31 May to 20 June 2007 and differed among habitats $\left(\chi^{2}=18.71, \mathrm{df}=2, P<0.01\right)$. Post hoc comparisons revealed that nests were initiated earlier in shelters than in the two other habitats (nest shelters vs. open habitats: $Z=-3.15, P<0.01$; nest shelters vs. woody vegetation: $Z=-4.15, P<0.01$; open habitats vs. woody vegetation: $Z=-0.68, P=0.50)$. The NIDs did not differ between albumen-sampled nests and non-albumen-sampled nests in nest shelters $(Z=0.29, \mathrm{df}=1, P=0.78)$ or in open habitats $(Z=$ $-0.64, \mathrm{df}=1, P=0.53$ ), but they were earlier in albumen-sampled nests than in nonsampled nests in woody vegetation $(Z=-3.80$, $\mathrm{df}=1, P<0.01)$. Hence, our sampling was biased toward earlier nesters in the latter habitat. However, the overall timing of IEF sampling did not differ among habitats $\left(\chi^{2}=4.02, \mathrm{df}=2, P=0.13\right)$.

Overall apparent nest success for the laying and incubation period was $75 \%$ ( 180 of 239). Nest failure was caused by predation (69\%; 41 of 59 marked nests) and nest abandonment (31\%; 18 of 59 marked nests). Only avian predators were present at our study site-for example, Greater Black-backed Gulls (Larus marinus), Herring Gulls (L. argentatus), and Common Ravens (Corvus corax). The results of model selection suggest that nest survival varied among habitats, rather than among nesting islands (Table 2). Albumen sampling did not negatively affect nest survival. Top models $\left(\mathrm{QAIC}_{\mathrm{c}}\right.$ weight $\left.\approx 1.00\right)$ for nest survival included additive effects of habitat, clutch size, pseudothreshold age trend, and NID, as well as interactions between habitat and CS (Table 2). Daily nest survival was lowest during the egg-laying period and increased over the course of the nesting period (Fig. 2). Nests initiated earlier had higher survival than those initiated later $\left(\beta_{\text {NID }}=-0.09\right.$; $95 \%$ CI: -0.18 to 0.002$)$. Model-averaged nest survival estimates indicated that nest survival was highest in woody vegetation $(0.70$; 95\% CI: $0.50-0.89)$, followed by nest shelters (0.51; 95\% CI: 0.28 $0.75)$ and nests in open habitats $(0.34$; $95 \%$ CI: $0.09-0.58)$. The results of model averaging suggest that nest survival was highest for clutches slightly below mean CS, with a general decline in nest survival as CS increased (Fig. 3). Nest survival for all clutch sizes was lower in open habitats than in nest shelters or dense woody vegetation (Fig. 3).

Nest parasitism.-In total, $55 \%$ of sampled nests (22 of 40$)$ contained eggs from multiple females, and $18 \%$ of eggs (37 of 200)

TABLE 1. Number of nests, mean nest initiation dates, and mean final clutch sizes for Common Eiders nesting in three habitats (nest shelters, open grassy vegetation, and dense woody vegetation) at Table Bay, Labrador, Canada, in 2007.

\begin{tabular}{|c|c|c|c|c|c|c|c|}
\hline \multirow[b]{2}{*}{ Parameter } & \multirow[b]{2}{*}{ Overalla } & \multicolumn{3}{|c|}{ All nests } & \multicolumn{3}{|c|}{ Albumen-sampled nests ${ }^{b}$} \\
\hline & & Nest shelters & $\begin{array}{l}\text { Open grassy } \\
\text { vegetation }\end{array}$ & $\begin{array}{c}\text { Dense woody } \\
\text { vegetation }\end{array}$ & Nest shelters & $\begin{array}{l}\text { Open grassy } \\
\text { vegetation }\end{array}$ & $\begin{array}{c}\text { Dense woody } \\
\text { vegetation }\end{array}$ \\
\hline Nests $(n)$ & 239 & 79 & 72 & 88 & 14 & 11 & 15 \\
\hline Nest initiation date (NID) & 8 June & 7 June & 9 June & 9 June & 7 June & 8 June & 7 June \\
\hline Julian date \pm SD & $159.2 \pm 3.6$ & $157.9 \pm 4.0$ & $159.7 \pm 3.5$ & $160.0 \pm 3.0$ & $157.8 \pm 2.1$ & $159.2 \pm 1.9$ & $157.6 \pm 1.2$ \\
\hline Clutch size $(\mathrm{CS}) \pm \mathrm{SD}$ & $4.5 \pm 1.4$ & $4.9 \pm 1.6$ & $4.0 \pm 1.3$ & $4.4 \pm 1.2$ & $5.5 \pm 1.1$ & $4.4 \pm 0.8$ & $5.0 \pm 2.1$ \\
\hline Minimum CS & 1 & 1 & 1 & 2 & 4 & 3 & 3 \\
\hline Maximum CS & 10 & 10 & 8 & 10 & 7 & 6 & 10 \\
\hline
\end{tabular}

a Includes nests from all habitats.

${ }^{b}$ Nests from which albumen samples were analyzed, a subset of the total 239 surveyed nests (see text). 
TABLE 2. Candidate models of Common Eider nest survival for 239 sampled nests at Table Bay, Labrador, Canada, in 2007. Parameter estimates included nest habitat ( $\mathrm{Hab}$ ), nesting island (Island), the effect of albumen sampling (Alb), linear age trend (Age), quadratic age trend $\left(\mathrm{Age}^{2}\right)$, pseudothreshold age trend (LnAge), nest initiation date (NID), optimal nest initiation date $\left(\mathrm{NID}^{2}\right)$, clutch size $(\mathrm{CS})$, optimal clutch size $\left(\mathrm{CS}^{2}\right)$, and constant daily survival. Models are ranked in accordance with QAIC values ( $\hat{c}$ adjusted to 1.22 ) and are denoted as additive models ( + ) or models with single and interactive effects $\left({ }^{*}\right) . K=$ number of estimable parameters.

\begin{tabular}{|c|c|c|c|c|}
\hline Model & $K$ & $\Delta \mathrm{QAIC}_{\mathrm{c}}^{\mathrm{a}}$ & $\begin{array}{l}\text { QAIC }_{c} \\
\text { weights }\end{array}$ & QDeviance \\
\hline $\mathrm{S}\left({ }_{\left.\mathrm{Hab}+\text { LnAge }+\mathrm{NID}+\mathrm{CS}^{2}\right)}\right.$ & 8 & 0.00 & 0.26 & 235.12 \\
\hline $\mathrm{S}\left({ }_{\mathrm{Hab}+\text { LnAge }+\mathrm{NID}+\mathrm{CS}}\right)$ & 7 & 0.10 & 0.25 & 237.23 \\
\hline $\mathrm{S}\left(\mathrm{Hab}+\mathrm{LnAge}+\mathrm{NID}+\mathrm{CS}^{2}+\mathrm{Hab}^{*} \mathrm{CS}^{2}\right)$ & 12 & 0.93 & 0.17 & 228.00 \\
\hline $\mathrm{S}\left(\mathrm{Hab}+\right.$ LnAge $\left.+\mathrm{CS}^{2}\right)$ & 7 & 1.30 & 0.14 & 238.42 \\
\hline $\mathrm{S}(\mathrm{Hab}+$ LnAge + CS $)$ & 6 & 1.90 & 0.10 & 241.03 \\
\hline $\mathrm{S}\left({ }_{\mathrm{Hab}+\mathrm{LnAge}+\mathrm{NID}+\mathrm{CS}+\mathrm{Hab}^{*} \mathrm{CS}}\right)$ & 9 & 3.93 & 0.04 & 237.04 \\
\hline $\mathrm{S}\left(\begin{array}{c}\mathrm{Hab}+\text { LnAge } \\
)\end{array}\right.$ & 5 & 5.21 & 0.02 & 246.35 \\
\hline $\mathrm{S}(\mathrm{Hab}+$ LnAge + NID $)$ & 6 & 6.52 & 0.01 & 245.66 \\
\hline $\mathrm{S}(\mathrm{Hab}+\mathrm{Age})$ & 5 & 7.00 & 0.01 & 248.14 \\
\hline $\mathrm{S}\left(\mathrm{Hab}_{\mathrm{Hab}+\mathrm{Age}^{2}}{ }^{2}\right)$ & 6 & 7.94 & 0.00 & 247.07 \\
\hline $\mathrm{S}\left(\mathrm{Hab}_{\mathrm{Hab}}\right) \mathrm{Age}^{-}$ & 4 & 11.69 & 0.00 & 254.84 \\
\hline $\mathrm{S}(\mathrm{Hab}+\mathrm{Alb})$ & 5 & 13.60 & 0.00 & 254.74 \\
\hline $\mathrm{S}()$. & 2 & 14.50 & 0.00 & 261.66 \\
\hline$S\left({ }_{A l b}\right)$ & 3 & 16.44 & 0.00 & 261.59 \\
\hline $\mathrm{S}($ Island $)$ & 8 & 16.63 & 0.00 & 290.61 \\
\hline $\mathrm{S}\left({ }_{\mathrm{Hab} * \mathrm{Alb}}\right)$ & 7 & 17.18 & 0.00 & 254.30 \\
\hline $\mathrm{S}\left({ }_{\text {Island }+\mathrm{Alb}}\right)$ & 9 & 18.61 & 0.00 & 290.57 \\
\hline $\mathrm{S}($ Island*Alb $)$ & 12 & 23.94 & 0.00 & 289.77 \\
\hline
\end{tabular}

${ }^{\mathrm{a}}$ Lowest $\mathrm{QAIC}_{\mathrm{c}}$ value $=251.71$.

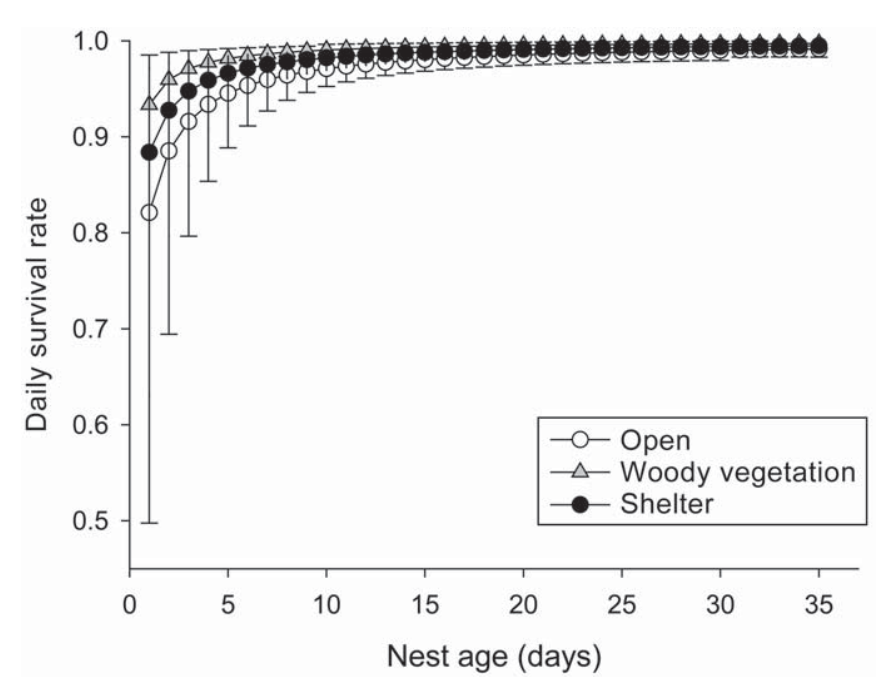

FIG. 2. Estimates of daily survival rates of Common Eider nests and 95\% confidence intervals from three different nesting habitats at Table Bay, Labrador, Canada, in 2007. Values were calculated using the logitlink function and are the weighted averages based on 18 candidate models.

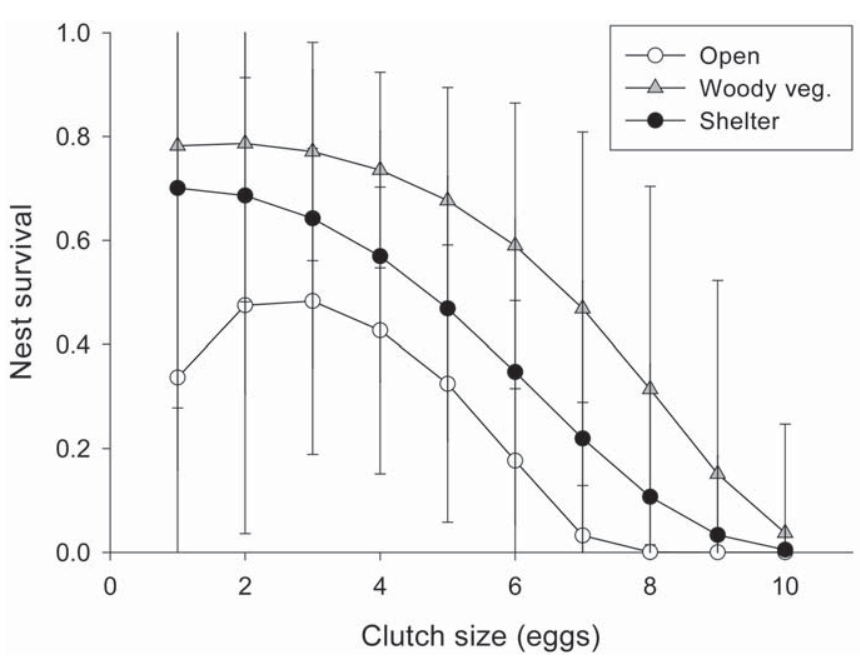

FIG. 3. Influence of clutch size on nest survival as predicted by models for Common Eider nests in three different habitats at Table Bay, Labrador, Canada, in 2007. The relationship is based on weighted model averages. Data were backtransformed from the logit scale, and confidence limits were derived using the delta method.

were laid parasitically. An average of 1.7 eggs nest ${ }^{-1}$ were added to parasitized nests. Most nests of mixed maternity contained a single foreign egg ( $55 \%$; 12 of 22 nests). Five nests contained two parasitic eggs, and another five nests contained three parasitic eggs. Three nests contained eggs from three different females. Parasitic laying was not distributed evenly among habitats $\left(\chi^{2}=18.64, \mathrm{df}=\right.$ $2, P<0.01)$. Nests in shelters had the highest frequency of brood parasitism ( $78 \%$; 11 of 14 nests), versus $54 \%$ of nests (6 of 11) in open habitats and $33 \%$ of nests ( 5 of 15 ) in woody vegetation. Overlapping 95\% CIs suggest that nest survival of parasitized nests and nonparasitized nests did not differ (0.65 [95\% CI: 0.41-0.83] and 0.58 [95\% CI: 0.33-0.80], respectively). All parasitic eggs were deposited during the egg-laying period or during the first days of incubation, and most parasitic eggs $(73 \% ; 27$ of 37$)$ were laid before our initial nest visits. We were unable to determine the exact timing of brood parasitism during the egg-laying sequence because we found few nests at the one-egg stage, and our nest visits were limited to once every 3 to 4 days. However, because we conducted nest checks throughout incubation, we could confirm that no eggs were deposited in nests after the main egg-laying period.

\section{Discussion}

Our estimated rate of CBP (55\%) is among the highest reported for Common Eiders (cf. $42 \%$ and 31\%, respectively, in Robertson et al. 1992, Waldeck and Andersson 2006). Nest parasitism at our study site was not evenly distributed among habitats and did not follow the pattern predicted by the risk assessment hypothesis (Pöysä 1999, 2006; Pöysä and Pesonen 2007). Nests in dense woody vegetation had the highest rates of nest survival but the lowest frequency of $\mathrm{CBP}$-results that were inconsistent with our initial predictions. On the other hand, we observed higher-than-normal rates of CBP in nest shelters, compared with other habitats. Although nest shelters were a relatively safe nesting environment in 
comparison to open habitats, we suggest that visibility and availability of suitable host nests (Semel et al. 1988, Lyon 2003, Roy Nielsen et al. 2006a) played more important roles than nest safety in influencing where nest parasites deposited their eggs.

Nest-site safety vs. visibility.-Nest safety is a primary selective force in shaping habitat selection (Ricklefs 1969; Martin 1988, 1993) and, thus, can influence CBP behavior (Pöysä and Pesonen 2007, Roy Nielsen et al. 2008). Recent studies suggest that brood parasites can increase the probability of their eggs' survival by preferentially depositing eggs in safe nest sites (risk assessment hypothesis; Pöysä 1999, 2006; Pöysä and Pesonen 2007). Central to this hypothesis is the premise that nest parasites gain information about nest-site safety through nest prospecting (Robertson 1998, Pöysä 2006, Roy et al. 2009). Information gathered during prospecting, such as the presence of a female at a site (Wilson 1993), the presence of eggs, or evidence of past success, may be useful cues when a safe nest site is selected. However, unlike cavity nesters that prospect for nest sites at the end of the season (Eadie and Gauthier 1985, Zicus and Hennes 1989, Pöysä 1999), Common Eiders prospect upon arrival at breeding areas (Robertson 1998). We suggest that shelters are used more by parasites because they (1) are highly visible and easily found and observed for host activity, (2) provide protection against avian nest predators and increase the probability that a parasite will find a host nest during laying, and (3) protect evidence of previous nesting attempts from being scattered by wind and precipitation, making shelters attractive to both normal nesters and parasites (see Roy et al. 2009, Fast et al. 2010). This supports the notion that nest visibility strongly influences CBP (Semel et al. 1988, Semel and Sherman 1995) and that nests in open areas are more likely to be parasitized than those in more concealed locations (Payne 1977). Although brood parasites could have potentially benefited from laying in the safest sites (i.e., nests in dense woody vegetation), the benefits may have been outweighed by the increased effort required to locate these nests (Rohwer and Freeman 1989).

In the absence of parasite strategies that target more concealed nests (e.g., Fiorini et al. 2009), nests in more exposed areas would, by chance alone, have been more likely to receive greater prospecting than more concealed nests. Recent evidence suggests that parasitic laying in combination with normal nesting (i.e., dual strategy; Sorenson 1991) may be a commonly used strategy (Reichart et al. 2010). Because normal nesting reduces the opportunity for individuals to parasitize the nests of others (Westneat and Sherman 1993), we suggest that individuals that engage in a dual strategy would benefit most if they used highly visible nest sites because this minimizes time spent searching for suitable host nests so that most of their time is spent attending to their own nests. This may be particularly important for colonial-nesting species that exhibit synchronous nest initiation.

Nest availability.-Successful parasitism requires temporal and spatial nest-site availability (Lyon 2003, Shaw and Hauber 2009). Because of the synchronous nature of nest initiation in Common Eiders (Cooch 1965, Swennen et al. 1993, present study), parasites have a relatively small window of opportunity to find suitable host nests. Common Eiders also exhibit a high degree of nest attendance before clutch completion and almost continuous attendance once incubation has begun (Swennen et al. 1993, Criscuolo et al. 2002, Bolduc and Guillemette 2003). Although these behaviors are thought to have evolved to reduce the potential for egg predation (see Korschgen 1977, Andersson and Waldeck 2006), they likely limit exposure to brood parasites. Our results seem to support this idea, given that nest survival increased considerably at the onset of incubation and no eggs were laid parasitically after the main egg-laying period.

Behaviors that restrict opportunities for CBP and the small clutch size of Common Eiders $(\bar{x}=4.5)$ likely contributed to the relatively low number of parasitic eggs per nest. We found no reductions in nest survival attributable to CBP, despite an overall high frequency of CBP (see also Robertson 1998, Roy Nielsen et al. 2006b). This may partially explain why aggressive interactions between female Common Eiders do not seem to occur (Robertson 1998), in contrast with other host-parasite systems (e.g., Sorenson 1997).

Conclusions and future studies.-Brood parasites appear to be selective in choosing where they lay their eggs. However, the choice of nest site seems to be based on overall nest visibility rather than nest-site safety. Although IEF helped to determine the frequency of nest parasitism, genetic data combined with molecular techniques will be necessary to understand whether Common Eiders employ dual nesting strategies (e.g., Reichart et al. 2010). Future studies that examine differences between hosts and brood parasites in terms of embryo quality and incubation effects (e.g., Pilz et al. 2005, DuRant et al. 2010) and recruitment of parasite and host young would be helpful in elucidating the ultimate benefits of CBP.

\section{ACKNOWLEDGMENTS}

We thank T. Elson, M. D’Entremont, L. Hamel, L. Turmel, J. Martin, A. Saunders, and R. Wells for help with logistics and assistance in the field. We are grateful to the Hamel and Burdett families for their hospitality in Cartwright, Newfoundland. We thank three anonymous reviewers for comments on the manuscript. Funding was provided by Ducks Unlimited Canada, Department of Biology and School of Graduate Studies of Memorial University, Atlantic Cooperative Wildlife Ecology Research Network, Northern Scientific Training Program, Quebec Labrador Foundation, University of North Dakota, and Experimental Program to Stimulate Competitive Research. Isoelectric focusing analysis was conducted by S. Rai at the Saskatchewan Research Council, Saskatoon. Field work was conducted under permits from the Canadian Wildlife Service and Environment Canada. This study was conducted in accordance with the Canadian Council on Animal Care guidelines (MUN animal care permit 07-01-IJ).

\section{Literature Cited}

ÅHLund, M., AND M. Andersson. 2001. Female ducks can double their reproduction. Nature 414:600-601.

AKAIKE, H. 1973. Information theory as an extension of the maximum likelihood principle. Pages 267-281 in Second International Symposium on Information Theory (B. N. Petrov and F. Csaki, Eds.). Akademiai Kiado, Budapest.

Anderson, D. R., K. P. Burnham, And G. C. White. 1994. AIC model selection in overdispersed capture-recapture data. Ecology 75:1780-1793. 
Andersson, M. 1984. Brood parasitism within species. Pages 195228 in Producers and Scroungers: Strategies of Exploitation and Parasitism (C. J. Barnard, Ed.). Croom Helm, London.

Andersson, M., AND M. ÅHLund. 2001. Protein fingerprinting: A new technique reveals extensive conspecific brood parasitism. Ecology 85:1433-1442.

Andersson, M., And P. WAldeCK. 2006. Reproductive tactics under severe egg predation: An eider's dilemma. Oecologia 148:350-355.

Avilés, J. M. 2008. Egg colour mimicry in the Common Cuckoo Cuculus canorus as revealed by modelling host retinal function. Proceedings of the Royal Society of London, Series B 275:23452352.

BJORn, T. H., AND K. E. ERIKSTAD. 1994. Patterns of intraspecific nest parasitism in the High Arctic Common Eider (Somateria mollissima borealis). Canadian Journal of Zoology 72:1027-1034.

Bolduc, F., AND M. Guillemette. 2003. Incubation constancy and mass loss in the Common Eider Somateria mollissima. Ibis 145:329-332.

Burnham, K. P., And D. R. Anderson. 2002. Model Selection and Multimodel Inference: A Practical Information-Theoretic Approach, 2nd ed. Springer-Verlag, New York.

Cooch, F. G. 1965. The breeding biology and management of the Northern Eider (Somateria mollissima borealis) in the Cape Dorset area, Northwest Territories. Canadian Wildlife Service Wildlife Management Bulletin Series 2, no. 10.

Cooper, J. A. 1978. The history and breeding biology of the Canada Geese of Marshy Point, Manitoba. Wildlife Monographs, no. 61.

Criscuolo, F., G. W. Gabrielsen, J.-P. Gendner, and Y. Le MAно. 2002. Body mass regulation during incubation in female Common Eiders Somateria mollissima. Journal of Avian Biology 33:83-88.

Davies, N. B. 2000. Cuckoos, Cowbirds and Other Cheats. T. \& A.D. Poyser, London.

Dinsmore, S. J., G. C. White, And F. L. KnOpf. 2002. Advanced techniques for modeling avian nest survival. Ecology 83:34763488 .

DuRant, S. E., G. R. Hepp, I. T. Moore, B. C. Hopkins, and W. A. Hopkins. 2010. Slight differences in incubation temperature affect early growth and stress endocrinology of Wood Duck (Aix sponsa) ducklings. Journal of Experimental Biology 213:45-51.

EAdie, J. MCA., AND G. GAuThier. 1985. Prospecting for nest sites by cavity-nesting ducks of the genus Bucephala. Condor 87:528534.

Fast, P. L. F., H. G. Gilchrist, and R. G. Clark. 2010. Nest-site materials affect nest-bowl use by Common Eiders (Somateria mollissima). Canadian Journal of Zoology 88:214-218.

Fiorini, V. D., D. T. Tuero, And J. C. ReboredA. 2009. Host behaviour and nest-site characteristics affect the likelihood of brood parasitism by Shiny Cowbirds on Chalk-browed Mockingbirds. Behaviour 146:1387-1403.

Franklin, A. B., D. R. Anderson, R. J. Gutiérrez, And K. P. Burnham. 2000. Climate, habitat quality, and fitness in Northern Spotted Owl populations in northwestern California. Ecological Monographs 70:539-590.

Guignion, D. 1968. Clutch size and incubation period of the American Eider (Somateria mollissima dresseri) on Brandypot Island. Naturaliste Canadien 95:1145-1152.
Hauber, M. E. 2000. Nest predation and cowbird parasitism in Song Sparrows. Journal of Field Ornithology 71:389-398.

Hauber, M. E. 2001. Site selection and repeatability in BrownHeaded Cowbird (Molothrus ater) parasitism of Eastern Phoebe (Sayornis phoebe) nests. Canadian Journal of Zoology 79:15181523.

HAUBER, M. E. 2009. Does the removal of avian brood parasite eggs increase host productivity? A case study with Brown-Headed Cowbirds Molothrus ater and Song Sparrows Melospiza melodia near Ithaca, New York, USA. Conservation Evidence 6:8388.

Kattan, G. H. 1997. Shiny Cowbirds follow the 'shotgun' strategy of brood parasitism. Animal Behaviour 53:647-654.

KING, J. R. 1974. Seasonal allocation of time and energy resources in birds. Pages 4-70 in Avian Energetics (R. A. Paynter, Jr., Ed.). Publications of the Nuttall Ornithological Club, no. 15.

Klett, A. T., H. F. Duebbert, C. A. FaAnes, and K. F. Higgins. 1986. Techniques for studying nest success of ducks in upland habitats in the prairie pothole region. U.S. Fish and Wildlife Service Resource Publication no. 158.

Korschgen, C. E. 1977. Breeding stress of female eiders in Maine. Journal of Wildlife Management 41:360-373.

KRÜGER, O. 2007. Cuckoos, cowbirds and hosts: Adaptations, tradeoffs and constraints. Philosophical Transactions of the Royal Society of London, Series B 362:1873-1886.

Little, R. J. A., AND D. B. Rubin. 2003. Statistical Analysis with Missing Data, 2nd ed. Wiley, Hoboken, New Jersey.

Lock, A. R. 1986. A census of Common Eiders breeding in Labrador and the Maritime provinces. Pages 30-38 in Eider Ducks in Canada (A. Reed, Ed.). Canadian Wildlife Service Report Series, no. 47.

LYON, B. E. 2003. Ecological and social constraints on conspecific brood parasitism by nesting female American Coots (Fulica americana). Journal of Animal Ecology 72:47-60.

MABEE, T. J. 1997. Using eggshell evidence to determine nest fate of shorebirds. Wilson Bulletin 109:307-313.

Martin, T. E. 1988. Habitat and area effects on forest bird assemblages: Is nest predation an influence? Ecology 69:74-84.

Martin, T. E. 1993. Nest predation and nest sites. BioScience 43:523-532.

PAyne, R. B. 1977. The ecology of brood parasitism in birds. Annual Review of Ecology and Systematics 8:1-28.

Pilz, K. M., H. G. Smith, And M. Andersson. 2005. Brood parasitic European Starlings do not lay high-quality eggs. Behavioral Ecology 16:507-513.

Polačiková, L., P. Procházka, M. Cherry, and M. Honza. 2009. Choosing suitable hosts: Common Cuckoos Cuculus canorus parasitize Great Reed Warblers Acrocephalus arundinaceus of high quality. Evolutionary Ecology 23:879-891.

Pöysä, H. 1999. Conspecific nest parasitism is associated with inequality in nest predation risk in the Common Goldeneye (Bucephala clangula). Behavioral Ecology 10:533-540.

Pöysä, H. 2003. Parasitic Common Goldeneye (Bucephala clangula) females lay preferentially in safe neighbourhoods. Behavioral Ecology and Sociobiology 54:30-35.

Pöysä, H. 2006. Public information and conspecific nest parasitism in goldeneyes: Targeting safe nests by parasites. Behavioral Ecology 17:459-465. 
Pöysä, H., ANd M. Pesonen. 2007. Nest predation and the evolution of conspecific brood parasitism: From risk spreading to risk assessment. American Naturalist 169:94-104.

Reichart, L. M., S. Anderholm, V. Muñoz-Fuentes, And M. S. WebSTER. 2010. Molecular identification of brood-parasitic females reveals an opportunistic reproductive tactic in Ruddy Ducks. Molecular Ecology 19:401-413.

RiCKLEFS, R. E. 1969. An analysis of nesting mortality in birds. Smithsonian Contributions to Zoology, no. 9.

Robertson, G. J. 1998. Egg adoption can explain joint egg-laying in Common Eiders. Behavioral Ecology and Sociobiology 43 289-296.

Robertson, G. J., M. D. Watson, And F. Cooke. 1992. Frequency, timing and costs of intraspecific nest parasitism in the Common Eider. Condor 94:871-879.

Rohwer, F. C., and S. Freeman. 1989. The distribution of conspecific nest parasitism in birds. Canadian Journal of Zoology 67:239-253.

Rothstein, S. I. 1976. Cowbird parasitism of the Cedar Waxwing and its evolutionary implications. Auk 93:498-509.

RothSTEIN, S. I. 1990. A model system for coevolution: Avian brood parasitism. Annual Review of Ecology and Systematics 21:481508.

Roy, C. L., J. M. Eadie, E. M. Schauber, N. S. Odell, E. C. Berg, AND T. Moore. 2009. Public information and conspecific nest parasitism in Wood Ducks: Does nest density influence quality of information? Animal Behaviour 77:1367-1373.

Roy Nielsen, C. L., R. J. Gates, and P. G. Parker. 2006a. Intraspecific nest parasitism of Wood Ducks in natural cavities: Comparisons with nest boxes. Journal of Wildlife Management 70:835-843.

Roy Nielsen, C. L., P. G. Parker, and R. J. Gates. 2008. Partia clutch predation, dilution of predation risk, and the evolution of intraspecific nest parasitism. Auk 125:679-686.

Roy Nielsen, C. L., B. Semel, P. W. Sherman, D. F. Westneat, AND P. G. PARKer. 2006b. Host-parasite relatedness in Wood Ducks: Patterns of kinship and parasite success. Behavioral Ecology 17:491-496.

Sargeant, A. B., And D. G. Raveling. 1992. Mortality during the breeding season. Pages 396-422 in Ecology and Management of Breeding Waterfowl (B. D. J. Batt, A. D. Afton, M. G. Anderson, C. D. Ankney, D. H. Johnson, J. A. Kaldec, and G. L. Krapu, Eds.) University of Minnesota Press, Minneapolis.

SAS InSTITUTE. 2001. SAS/STAT User's Guide. SAS Institute, Cary, North Carolina.

Schmidt, J. H., E. J. Taylor, and E. A. Rexstad. 2006. Surviva of Common Goldeneye ducklings in interior Alaska. Journal of Wildlife Management 70:792-798.

SEALY, S. G., AND R. C. BAZIN. 1995. Low frequency of observed cowbird parasitism on Eastern Kingbirds: Host rejection, effective nest defense, or parasite avoidance? Behavioral Ecology 6:140-145.

Seber, G. A. F. 1982. The Estimation of Animal Abundance and Related Parameters, 2nd ed. Macmillan, New York.
Semel, B., ANd P. W. Sherman. 1995. Alternative placement strategies for Wood Duck nest boxes. Wildlife Society Bulletin 23:463471.

Semel, B., P. W. Sherman, and S. M. Byers. 1988. Effects of brood parasitism and nest-box placement on Wood Duck breeding ecology. Condor 90:920-930.

Shaw, R. C., AND M. E. Hauber. 2009. Experimental support for the role of nest predation in the evolution of brood parasitism. Journal of Evolutionary Biology 22:1354-1358.

Soler, J. J., M. Soler, A. P. Møller, and J. G. Martínez. 1995 Does the Great Spotted Cuckoo choose magpie hosts according to their parenting ability? Behavioral Ecology and Sociobiology 36:201-206.

Sorenson, M. D. 1991. The functional significance of parasitic egg laying and typical nesting in Redhead Ducks: An analysis of individual behaviour. Animal Behaviour 42:771-796.

SORENSON, M. D. 1997. Effects of intra- and interspecific brood parasitism on a precocial host, the Canvasback, Aythya valisineria. Behavioral Ecology 8:153-161.

Swennen, C., J. C. H. Ursem, and P. Duiven. 1993. Determinate laying and egg attendance in Common Eiders. Ornis Scandinavica 24:48-52.

WAldeCK, P., AND M. Andersson. 2006. Brood parasitism and nest takeover in Common Eiders. Ethology 112:612-624.

Waldeck, P., M. Andersson, M. Kilpi, ANd M. Öst. 2008. Spatial relatedness and brood parasitism in a female-philopatric bird population. Behavioral Ecology 19:67-73.

WALDECK, P., M. KILPI, M. ÖST, AND M. ANDERSSON. 2004. Brood parasitism in a population of Common Eider (Somateria mollissima). Behaviour 141:725-739.

WeLLER, M. W. 1956. A simple field candler for waterfowl eggs. Journal of Wildlife Management 20:111-113.

Westneat, D. F., And P. W. Sherman. 1993. Parentage and the evolution of parental behavior. Behavioral Ecology 4:66.

White, G. C., AND K. P. BuRnham. 1999. Program MARK: Survival estimation from populations of marked animals. Bird Study 46 Supplement:S120-S139.

White, H. B. I. 1991. Maternal diet, maternal proteins, and egg quality. Pages 1-15 in Egg Incubation: Its Effects on Embryonic Development in Birds and Reptiles (D. C. Deeming and M. W. J. Ferguson, Eds.). Cambridge University Press, Cambridge, United Kingdom.

Wilson, S. F. 1993. Use of Wood Duck decoys in a study of brood parasitism. Journal of Field Ornithology 64:337-340.

Yom-Tov, Y. 2001. An updated list and some comments on the occurrence of intraspecific nest parasitism in birds. Ibis 143:133143.

Yom-Tov, Y., AND E. GeFFEn. 2006. On the origin of brood parasitism in altricial birds. Behavioral Ecology 17:196-205.

Zicus, M. C., AND S. K. Hennes. 1989. Nest prospecting by Common Goldeneyes. Condor 91:807-812.

Associate Editor: M. E. Hauber 